\title{
An Anatomical and Radiographic Study on the Vertebral Column of the Two-Toed Sloth (Choloepus hoffmanni)
}

\section{Estudio anatómico y radiográfico en la columna vertebral del perezoso de dos dedos (Choloepus hoffmanni)}

\section{Estudo anatômico e radiográfico da coluna vertebral do bicho-preguiça de dois dedos (Choloepus hoffmanni)}

\begin{abstract}
Maripaz Chinchilla-Barboza ${ }^{1 凶}$, Siam Chiquillo-Vergara ${ }^{1}$, Valeria Delgado-Álvarez ${ }^{1}$ Susan GutiérrezGutiérrez ${ }^{1}$, J. Steven Mora-Aleman ${ }^{1}$, Jonathan Gerardo Páez-Padilla ${ }^{1}$, Jorge Sanchez-Bermudez ${ }^{1}$, Andréia Passos-Pequeno².

1 Anatomy Department, Veterinary Medicine School, Universidad Nacional, Heredia, Costa Rica. E-mail: maripaz.chinchilla.

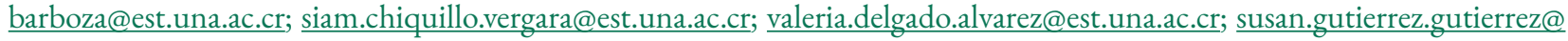
est.una.ac.cr; johnny.mora.aleman@est.una.ac.cr; jonathan.paez.padilla@est.una.ac.cr; jorge.sanchez.bermudez@est.una.ac.cr; andreia.passos.pequeno@una.cr
\end{abstract}

Received: June 24, 2020 Corrected: March 11, 2021 Accepted: April 23, 2021

\begin{abstract}
Resumen
El Choloepus hoffmanni es un mamífero del superorden Xenarthra que se distribuye desde América Central hasta América del Sur. Estos animales comúnmente llegan a los centros de atención y valoración de fauna silvestre víctimas de atropellamientos o agresiones por parte del humano y animales domésticos, por lo que las bases anatómicas son fundamentales para la práctica clinico-quirúrgica en esta especie. El objetivo del presente trabajo fue describir las características anatómicas y radiográficas de la columna vertebral del Choloepus hoffmanni. En este estudio se utilizaron cuatro especímenes de C. hoffmanni, los huesos de la columna vertebral se prepararon mediante hervido y macerado. Como resultados fue posible observar que el esqueleto axial del perezoso está compuesto por cinco tipos de vértebras notablemente distintas. Entre ellas fueron encontradas seis vértebras cervicales, un número variable de vértebras torácicas, vértebras lumbares xenartéricas y la fusión entre el sacro y los coxales. Finalmente, fueron identificadas cuatro vértebras caudales subdesarrolladas formando un pequeño muñón de cola. Radiográficamente, no se observaron desvíos anormales en ninguno de los segmentos de la columna ni tampoco alteraciones óseas o de estructuras adyacentes. En conclusión, el presente estudio describió tanto la osteología como la anatomía radiológica de la columna vertebral del C. hoffmanni detallando las similitudes y particularidades de esta especie en relación con mamíferos domésticos, así como otras especies del superorden Xenartra. Tal información es importante para el análisis forense de la vida silvestre, así como colaborar con el abordaje clínico-quirúrgico de lesiones en la columna vertebral en esta especie.
\end{abstract}

Palabras clave: Perezoso, Anatomía, Vértebras, Espina, Osteología.

$凶$

Autor de correspondencia: maripaz.chinchilla.barboza@est.una.ac.cr 


\begin{abstract}
The Choloepus Hoffmani is a mammal belonging to the Xenarthra superorder; xenarthrans are distributed from North to South America. It is common for these animals to require medical attention at wildlife rescue centers after being attacked by domestic animals or run over by cars. A proper understanding of this species' anatomy is vital in order to be able to offer them a proper level of clinical attention. This publication aims to describe the spine's anatomical and radiographic characteristics of the Choloepus Hoffmani. Four individuals were used in this research; the spine bones were cleaned by boiling and maceration. In the results, it was possible to observe how the postcranial axial skeleton in the sloths is made up by five of distinctive vertebra types. In the spine were found: six cervical vertebrae, a variable number of thoracic vertebrae, xenarthrous lumbar vertebrae, and a fusion between the sacrum and coxal bone. Finally, four underdeveloped caudal vertebrae were also identified in a small stump-like tail. Radiographically, no pathologies were observed in the alignment or structure of the spine. In conclusion, the present study described both the osteology alongside the anatomical radiography of the vertebral column of the Choloepus hoffmani, highlighting the particularities that are not found in domestic mammals and other members of the Xenarthra superorder. Information of this kind is relevant for forensic wildlife analysis, alongside aiding the treatment of animals in this species who suffered lesions in their spine.
\end{abstract}

Keywords: sloth, anatomy, vertebrae, spine, Osteology

\begin{abstract}
Resumo
O Choloepus hoffmanni é um mamífero da superordem Xenarthra que está distribuído desde a América Central à América do Sul. Estes animais chegam comumente aos Centros de Atenção e Avaliação da Fauna Silvestre vítimas de atropelamentos ou agressóes por humanos e animais domésticos, sendo, portanto, as bases anatômicas fundamentais para a prática clínico-cirúrgica nesta espécie. O objetivo do presente trabalho foi descrever as características anatômicas e radiográficas da coluna de Choloepus hoffmanni. Quatro indivíduos de C. hoffmanni foram usados neste estudo e os ossos da coluna foram preparados por fervura e maceração. Como resultados foi possível observar que o esqueleto axial do $C$. boffmanni é composto por cinco tipos notavelmente distintos de vértebras. Entre elas foram encontradas seis vértebras cervicais, um número variável de vértebras torácicas, vértebras lombares xenarterianas e a fusão entre o sacro e os ossos coxais. Finalmente, quatro vértebras caudais subdesenvolvidas foram identificadas, formando um curto segmento de cauda. Radiograficamente, não foram observados desvios anormais em nenhum dos segmentos espinhais, nem alteraçóes ósseas ou de estruturas adjacentes. Em conclusão, o presente estudo descreveu a osteologia e a anatomia radiológica da coluna vertebral de $C$. hoffmanni, detalhando as semelhanças e particularidades desta espécie em relação aos mamíferos domésticos, bem como outras espécies da superordem Xenartra. Tais informaçôes são importantes para a análise forense da fauna silvestre, bem como colaboram para a abordagem clínico-cirúrgica das lesões vertebrais nesta espécie.
\end{abstract}

Palavras-chave: Bicho-preguiça, Anatomia, Vértebras, Coluna vertebral, Osteologia.

\title{
Introduction
}

All animals belonging to the superorder Xenarthra are fascinating creatures full of unique traits that have merited study for decades. The superorder Xenarthra consists of 31 extant species of armadillos (Cingulata-Dasypodidae), sloths (Pilosa-Folivora: Bradypodidae and Megalonychidae), and anteaters (Pilosa-Vermilingua: Myrmecophagidae and Cyclopedidae) (Aguilar \& Superina, 2015).

The sloths are widely distributed, considering that they can be found in South and Central America (Gilmore et al., 2001; Torres-Trujillo \& Mantilla-Meluk 2016). Although the Choloepus hoffmanni is not listed as endangered species by the International Union for Conservation of Nature (IUCN), they commonly arrive at wildlife centers with traumas caused by fights with domestic dogs or accidents on roads.

2 Maripaz Chinchilla-Barboza, Siam Chiquillo-Vergara, Valeria Delgado-Álvarez, Susan Gutiérrez-Gutiérrez, J. Steven Mora-Aleman, Jonathan Gerardo Páez-Padilla, Jorge Sanchez-Bermudez, Andréia Passos-Pequeno 
Therefore, anatomical bases are necessary to perform better medical and surgical procedures. In sloths, the vertebrae number in the neck varies from the usual seven found in all mammals (Buchhostz \& Stepien, 2009). In fact, xenarthrans are characterized by the presence of (xenarthrous) extra joints in their lumbar vertebrae that strengthen their lower back and hips; also, the pelvis and sacrum are fused by an ossification process. Those differences in xenarthrans are extremely important for taxonomic, anatomical, and clinical studies in this unique species (Bargo \& Nyakatura 2010; Gardner 2016; Soibelzon et al., 2010).

In sloths, many of the differences that separate them from other mammals can be found in their axial skeleton. The vertebral column is of vital importance; it explains characteristics closely linked to the lifestyle of these animals. For example, some of the unique traits that define this species include a high number of thoracic vertebrae and ribs that are seen as an adaptation for the suspensory activity of $C$. hoffmanni in trees (Cliffe et al., 2014) and how the mammillary and transverse processes in C. hoffmanni join to form an extra joint that helps to reinforce the lumbar area (Gaudin \& Biewener, 1992).

Most of the information available on sloths to date has focused primarily on aspects of the animal's locomotion and hanging mechanisms in trees. However, there is a lack of updated information in terms of the gross anatomy of the axial skeletal, which is of importance for anyone who treat these species in a hospital or as an introduction before tackling the other available research. Bones are the foundation of the body, and a deep understanding of them facilitates decision-making when helping any living being that has them.

The objective of this project was to describe the anatomical and radiographic characteristics of the spine of the C. boffmanni.

\section{Materials and Methods}

The complete cadavers of three male and one female sloth that had passed away in the Hospital for Small and Wild Species of the National University of Costa Rica (HEMS) were donated to the Laboratory of Anatomy, School of Veterinary Medicine, Faculty of Medical Sciences, National University, Costa Rica. No abnormal deformities were detected in any of the specimens. The bodies of the animals were weighted, shaved and then manually dissected to remove all the soft tissue. The bones were then boiled in lime and water to remove any lingering remnant of soft tissue from them, to then be treated with 3\% hydrogen peroxide and dried in the sun. Photographs of the different vertebrae were taken using a Nikon digital camera model COOLPIX L810 and also were radiographed by using a digital X-ray system (Tingle X-ray, Cottondale, USA). Radiographic technical protocol ranged from 85 to $87 \mathrm{kVp}$ and $5 \mathrm{mAs}$ for the vertebral column. The nomenclature used in this study is in alignment with the sixth edition of the Nomina Anatomica Veterinaria.

\section{Results}

The postcranial axial skeleton of the sloth is composed of five remarkably distinct types of vertebrae. Only six cervical vertebrae were found, and the total number of thoracic vertebrae varied in the four studied animals. Extra joints in the lumbar vertebrae were observed in all the studied animals. Claims that indicated the fusion between the sacrum and the pelvis were reaffirmed after the fusion became visible upon dissection. The four specimens possessed four caudal vertebrae that formed a tail that was similar to a small stump. 
Table 1. Table depicting quantity of the different vertebrae found on the four specimens studied.

\begin{tabular}{ccccc}
\hline Vertebrae & Male\#1 & Male\#2 & Male\#3 & Female\#1 \\
\hline Cervical & 6 & 6 & 6 & 6 \\
Thoracic & 22 & 22 & 22 & 23 \\
Lumbar & 4 & 4 & 4 & 4 \\
Sacral & 8 & 8 & 8 & 8 \\
Caudal & 4 & 4 & 4 & 4 \\
\hline
\end{tabular}

\section{Cervical vertebrae}

The cervical spine in the C. hoffmanni starts with the atlas. This vertebra has two lateral wings, sustained by a pair of lateral masses (atlas lateral masses) directly attached to the rest of the vertebra (Fig.1). It has cranial and caudal articular foveas instead of the articular processes that are present in the regular vertebrae. Another difference is the presence of a dorsal tubercle and a ventral tubercle as well. Between these tubercles the vertebral foramen is visible. The atlas of the C. hoffmanni has a lateral vertebral foramen (Fig. 1) and also has an alar foramen on both sides close to the atlas wings. In order to form the atlantoaxial joint, the atlas has a fovea for the dens of the axis.

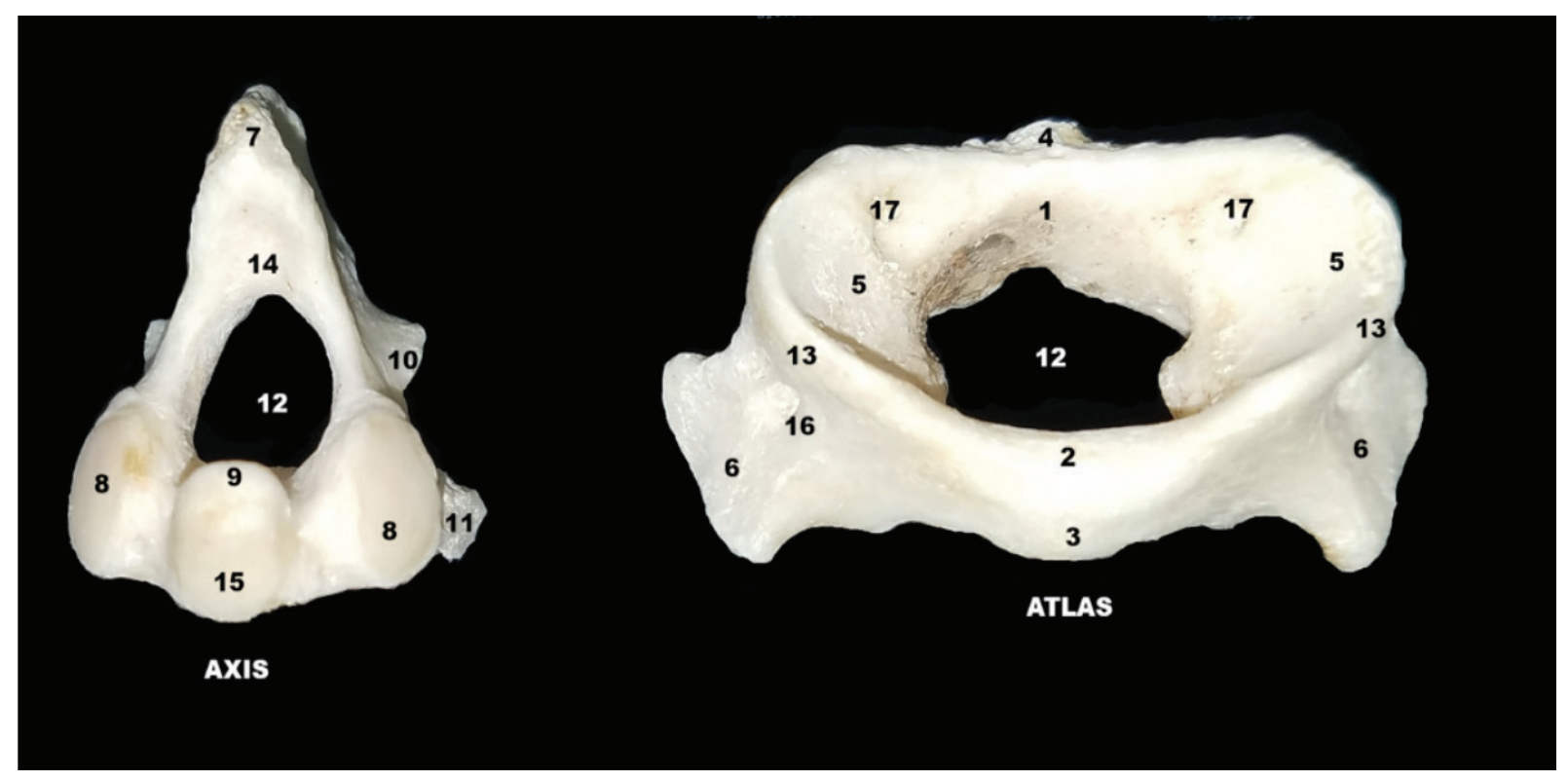

Figure 1. Cranial view of atlas and axis (C1 and C2). (1) Dorsal arch, (2) ventral arch, (3) ventral tubercle, (4) dorsal tubercle, (5) cranial articular fovea, (6) atlas wings, (7) spinous process, (8) cranial articular processes, (9) dens of the axis, (10) caudal articular process, (11) transverse process, (12) vertebral foramen, (13) atlas lateral masses, (14) axis arch, (15) axis body, (16) transverse hole, (17) lateral vertebral foramen. Photograph by the authors.

4 Maripaz Chinchilla-Barboza, Siam Chiquillo-Vergara, Valeria Delgado-Álvarez, Susan Gutiérrez-Gutiérrez, J. Steven Mora-Aleman, Jonathan Gerardo Páez-Padilla, Jorge Sanchez-Bermudez, Andréia Passos-Pequeno 
The axis is the first cervical vertebra that presents processes; the transverse processes are visible on both sides of the vertebral body. It has a prominent cranial, caudal, and spinous processes and articular processes as well (Fig. 2). The spinous process is more prominent in the axis than in other vertebrae. The axis' tooth projects cranioventrally towards the atlas' fovea for dens (Fig. 4). The vertebral body of the axis has a conical shape that encircles the vertebral canal alongside the arch (Fig. 1). Its caudal part articulates with C3 exactly between the caudal and cranial processes. There are thin interarcual spaces between the dorsal arches of adjacent vertebrae, which are wider in some specific places in the vertebral column. Two of these spaces in the cervical column are noticeably wide; they are the atlantooccipital space and the atlantoaxial space.

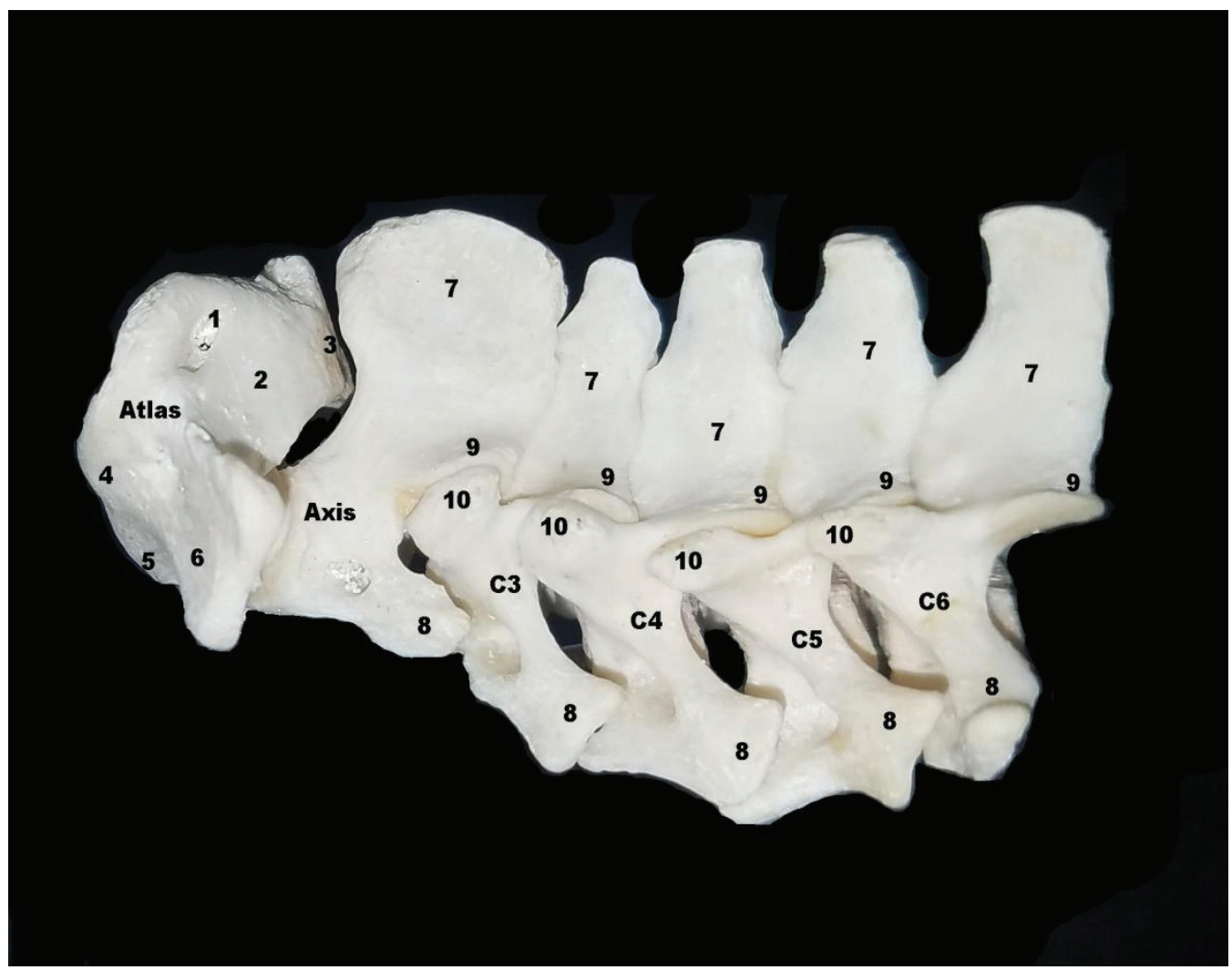

Figure 2. Lateral view of the cervical region of the spine, where the abnormal number of vertebrae is evident. (1) Alar foramen, (2) dorsal arch, (3) dorsal tubercle, (4) ventral arch, (5) ventral tubercle, (6) atlas wing, (7) spinous process, (8) transverse process, (9) caudal articular process, (10) cranial articular process. Photograph by the authors. 


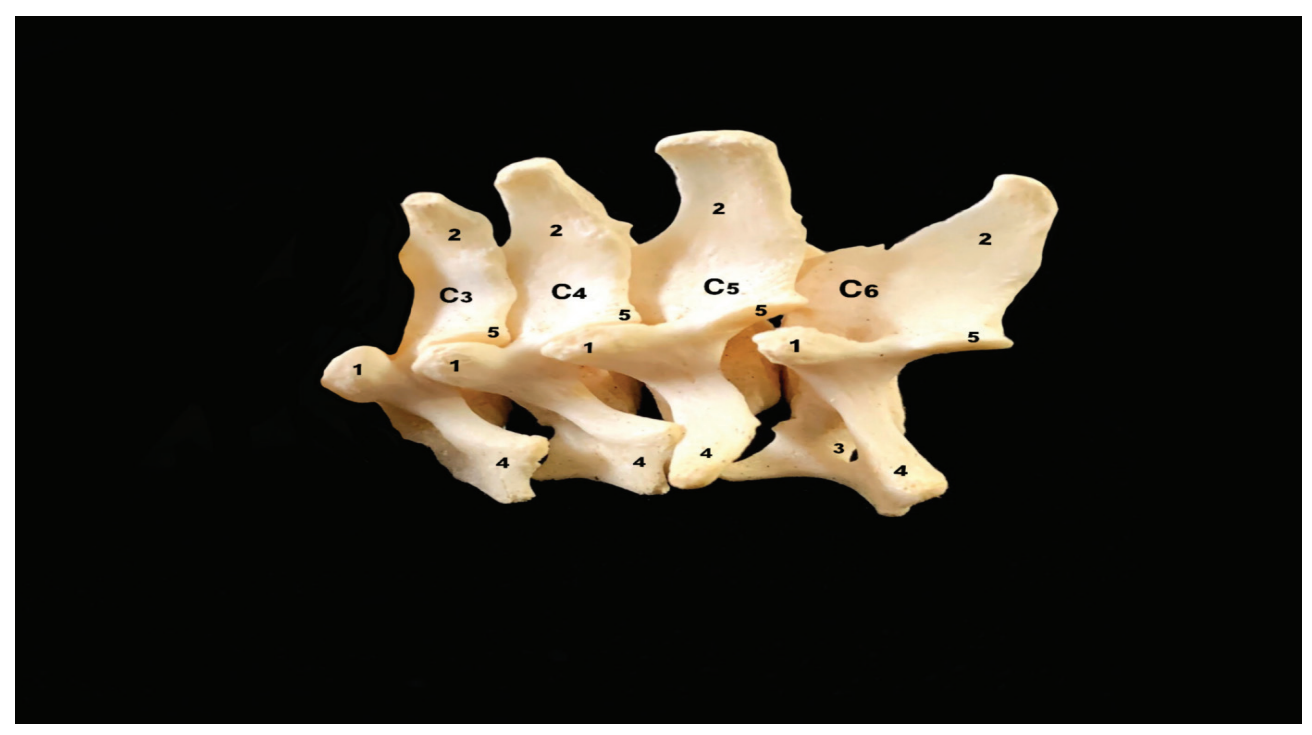

Figure 3. Lateral view of $\mathrm{C} 3$ to $\mathrm{C} 6$ (cervical vertebrae), (1) cranial articular process, (2) spinous process, (3) transverse foramen, (4) transverse process, (5) caudal articular process. Photograph by the authors.

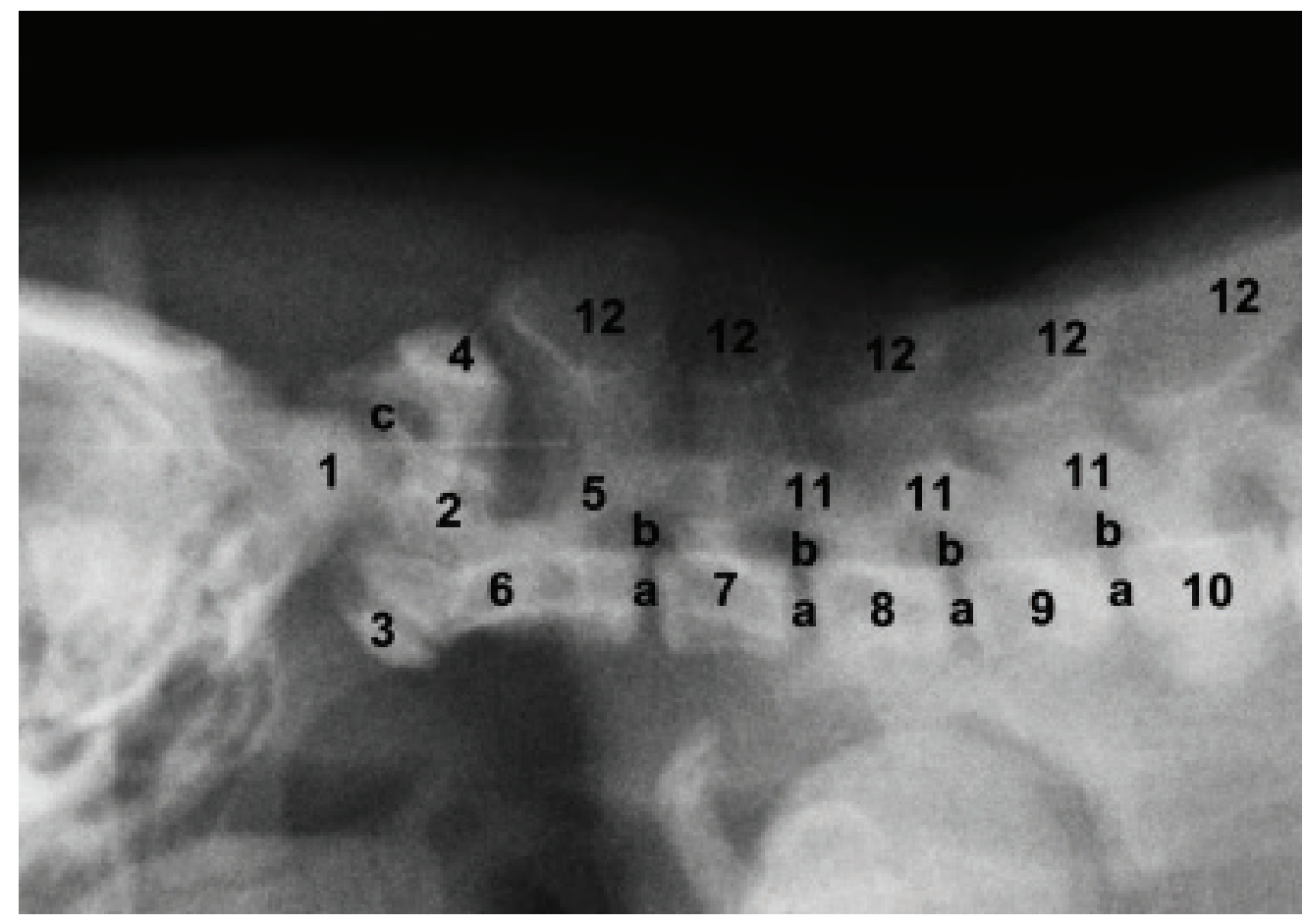

Figure 4. Right laterolateral X-rays showing the cervical spine of the C. hoffmanni. (1) Occipital condyle, (2) atlas, (3) atlas wings, (4) dorsal arch of the atlas, (5) axis, (6) transverse process, (7) vertebral body of C3, (8) vertebral body of C4, (9) vertebral body of C5, (10) vertebral body of C6, (11) cranial articular process, (12) spinous process, (a) intervertebral space, (b) intervertebral foramen, (c) atlantooccipital interarcuate space. Photograph by the authors. 
All of the C. hoffmanni's vertebrae from C3 to C6 vertebrae have minor morphological variations between them, which can make them difficult to differentiate (Fig.2). The transverse processes overlap with the adjacent processes of each vertebrae. In addition, from $\mathrm{C} 3$ to $\mathrm{C} 5$ there is a spinous, cranial, and caudal process. The typical cervical vertebrae have a body, an arch, and a transverse foramen, which is located on both sides of the vertebral body (Fig 3, 4). All the animals studied had a total of six cervical vertebrae. The transverse processes on the sixth cervical vertebra of the juvenile female had a distinctive shape that differed from the other typical cervical vertebrae.

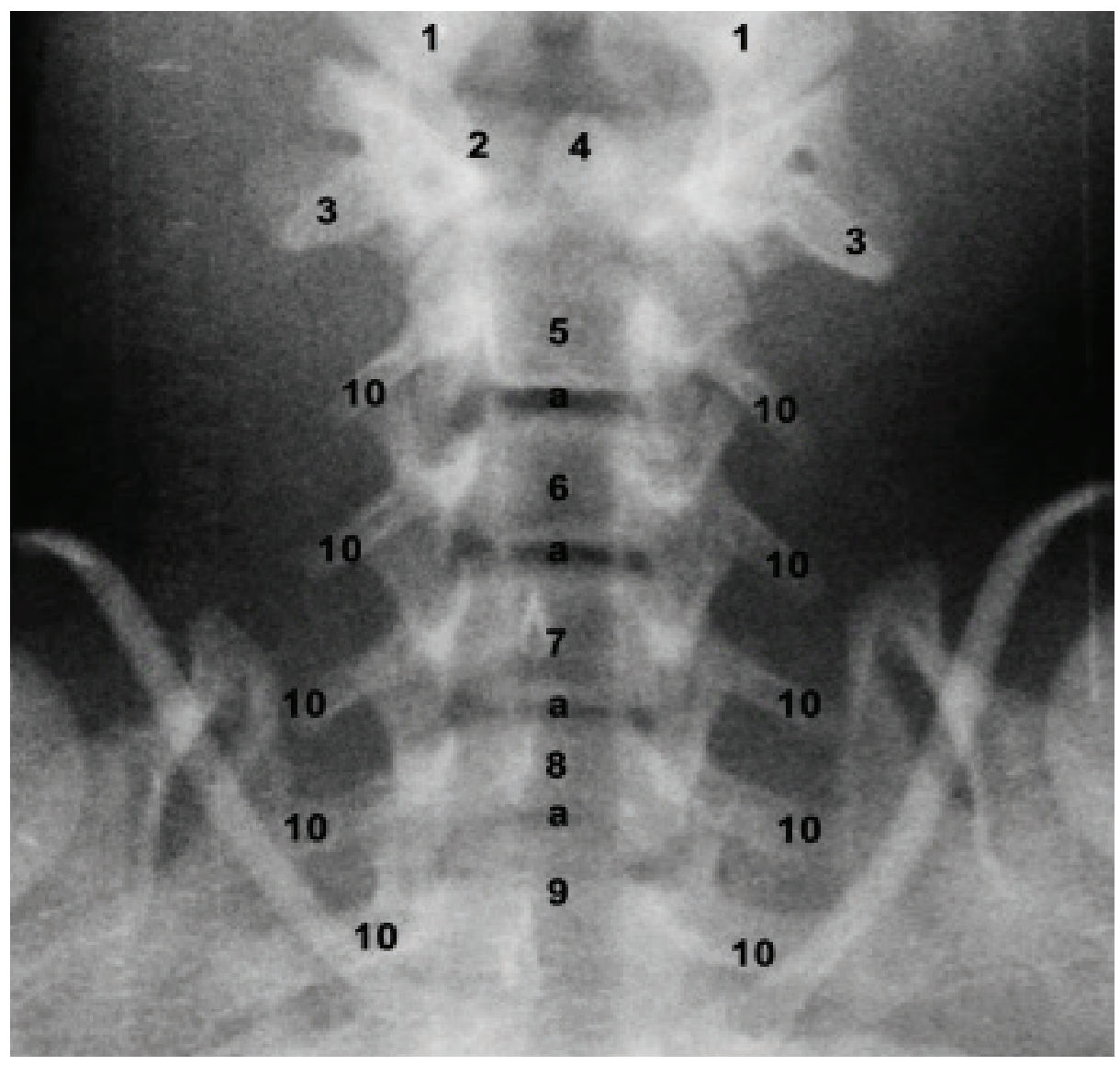

Figure 5. Ventrodorsal X-rays showing the cervical vertebrae of the C.hoffmanni. (1) Occipital condyle, (2) atlas, (3) atlas wings, (4) dens of the axis, (5) axis, (6) $3^{\text {rd }}$ cervical vertebrae, $(7) 4^{\text {th }}$ cervical vertebrae, $(8) 5^{\text {th }}$ cervical vertebrae, $(9) 6^{\text {th }}$ cervical vertebrae, $(10)$ transverse process, (a) intervertebral discs. Photograph by the authors.

\section{Thoracic Vertebrae}

The thoracic vertebrae are the most numerous ones in the spine, containing at least twenty-two different vertebrae in the studied sloths (Fig. 6). Each vertebra has a vertebral foramen, an arch, a body, two cranial and caudal articular processes, mammillary processes, a spinous process, two cranial costal facets, two 
caudal costal facets and cranial and caudal vertebral notches. The anticlinal vertebra could not be identified upon reviewing the X-ray images and after cleaning the bones of the animal (Fig. 7). X-ray imaging was also utilized to locate the animal's withers, the highest point between the scapulae was found to be the second thoracic vertebra (Fig. 7).

The cranial and articular processes are small, with flat and circular facets that form joints between the vertebrae. The spinous process is prominent in the more cranial thoracic vertebrae, with a thin laminar form protruding dorsally; however, it changes in size, becoming a flatter as the vertebral count becomes higher; the tallest and most developed spinous process was found between the scapulae.

The caudal vertebral incisures are deeper and more noticeable than the cranial ones. The transverse process of each vertebrae is convex ventrally to articulate with the rib's tubercle. C. hoffmanni's many thoracic vertebrae give the animal an elongated profile, with its ribcage encasing most of its viscera (Fig. 7, 8).

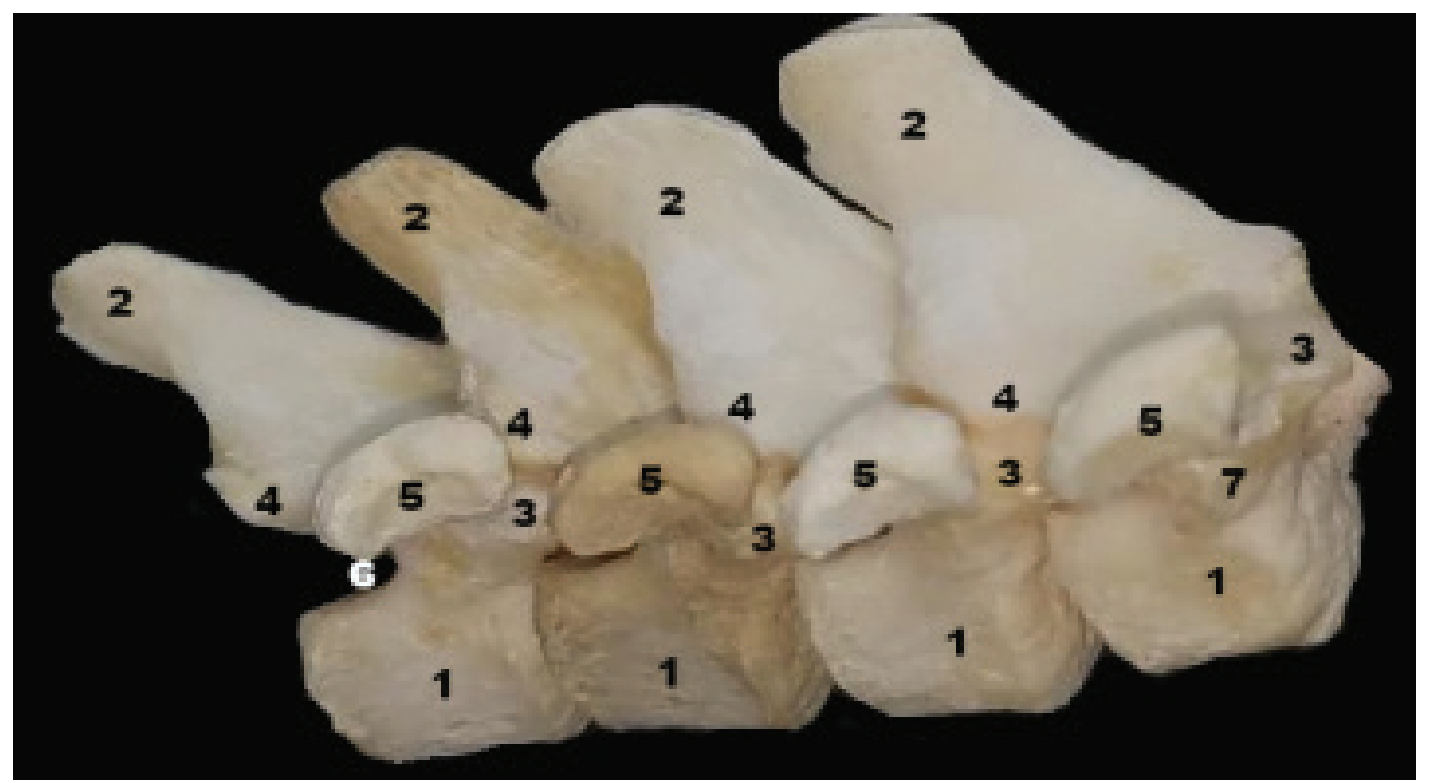

Figure 6. Lateral view of the first 3 thoracic vertebrae. (1) Body, (2) spinous process, (3) cranial articular process, (4) caudal articular process, (5) transverse process, (6) caudal vertebral incisure, (7) cranial costal facet. Photograph by the authors. 




Figure 7. Right laterolateral X-ray showing the abdomen of $C$. hoffmanni and its many thoracic vertebrae. (1) Vertebral body of T1, (2) vertebral body of T8, (3) vertebral body of T15, (4) vertebral body of T22, (5) spinous process, (a) intervertebral space, (b) intervertebral foramen. Photograph by the authors.

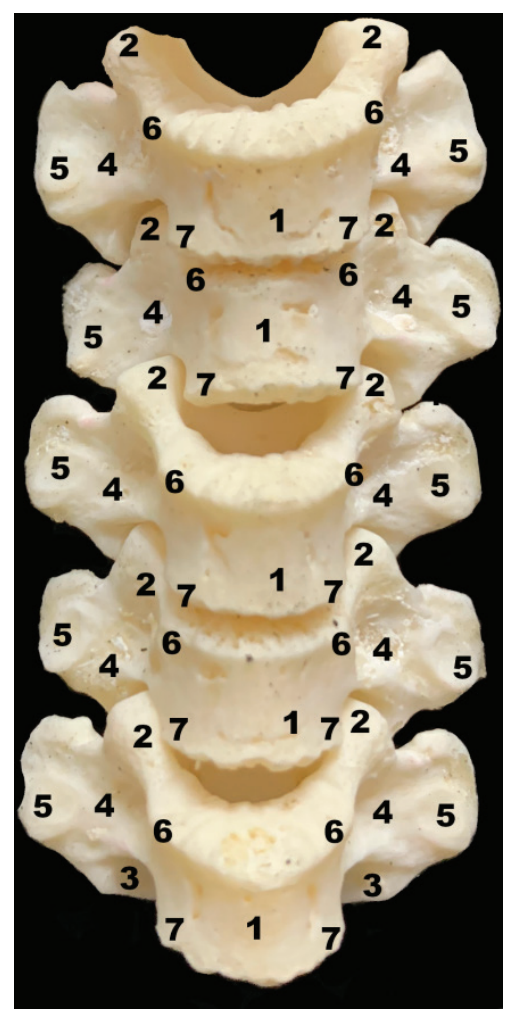

Figure 8. A ventral photograph of the thoracic vertebra of a C. hoffmanni. (1) Vertebral body, (2) cranial articular processes, (3) caudal articular processes, (4) transverse processes, (5) transverse costal facets, (6) cranial costal facet, (7) caudal costal facets. Photograph by the authors. 


\section{Lumbar Vertebrae}

A typical lumbar vertebra has an arch, a body, two cranial and caudal articular processes, two mammillary processes, a spinous process and cranial and caudal vertebral notches. The lumbar vertebrae differ from the thoracic vertebrae in that they are longer and have a more uniform shape to their bodies. The costal facets are absent; the spinous processes are considerably shorter and cranio-dorsally directed. The transverse processes are short in comparison with the domestic mammals and acquire a flattened form. The cranial and caudal extremities of the bodies present flat articular surfaces. The vertebral arches form a widened vertebral canal to accommodate the swelling of the spinal cord in the lumbar region, the caudal intumescence (Fig. 10).

The spinous processes are flat, forming a ramp-like structure located dorsal to each vertebra, as it is evidenced in the X-rays (Fig. 10). The size of the spinous process follows the trend shown by the last thoracic vertebrae as it decreases with every vertebra. The articular process is longer than the one in the thoracic vertebrae. The transverse process has the mammillary process above to form another joint that provides an extra spinal support (Fig. 9). The first lumbar vertebra has the shortest transverse process; the longest lumbar vertebra is the fourth and carries the longest transverse process.

The studied specimens had three joint areas at the lumbar vertebrae: cranial and caudal articular process, vertebral body with intervertebral discs and transverse process with a ventral area of the mammillary process. The interarcuate spaces are narrow in the lumbar region, but wide between the last lumbar and the first sacral vertebra, forming the lumbosacral interarcuate space, which can be used to access the vertebral canal (Fig. 10).

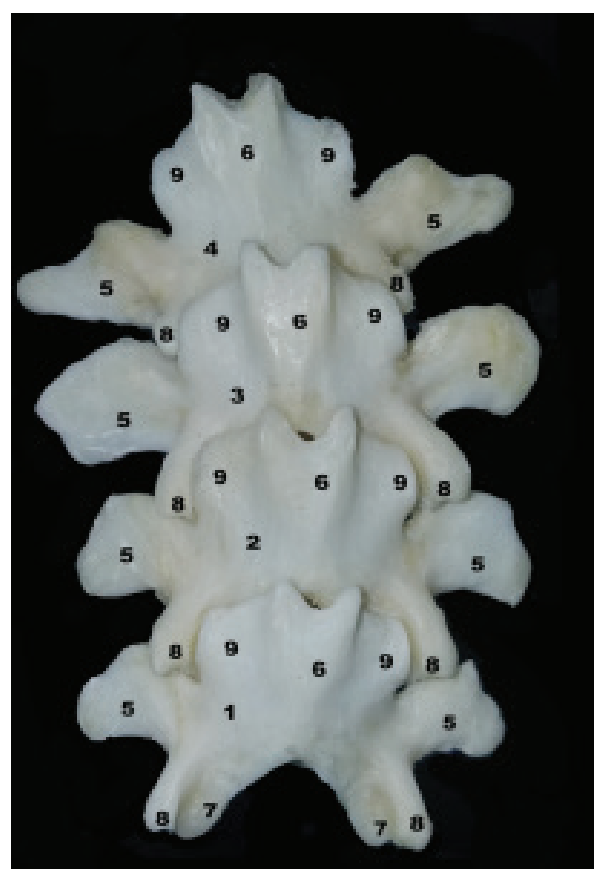

Figure 9. Dorsal view of C. hoffmanni lumbar spine. (1) $1^{\text {st }}$ lumbar vertebra, (2) $2^{\text {nd }}$ lumbar vertebra, (3) $3^{\text {rd }}$ lumbar vertebra, (4) $4^{\text {th }}$ lumbar vertebra, (5) transverse process, (6) spinous process, (7) cranial articular process, (8) mammillary process, (9) caudal articular process. Photograph by the authors. 


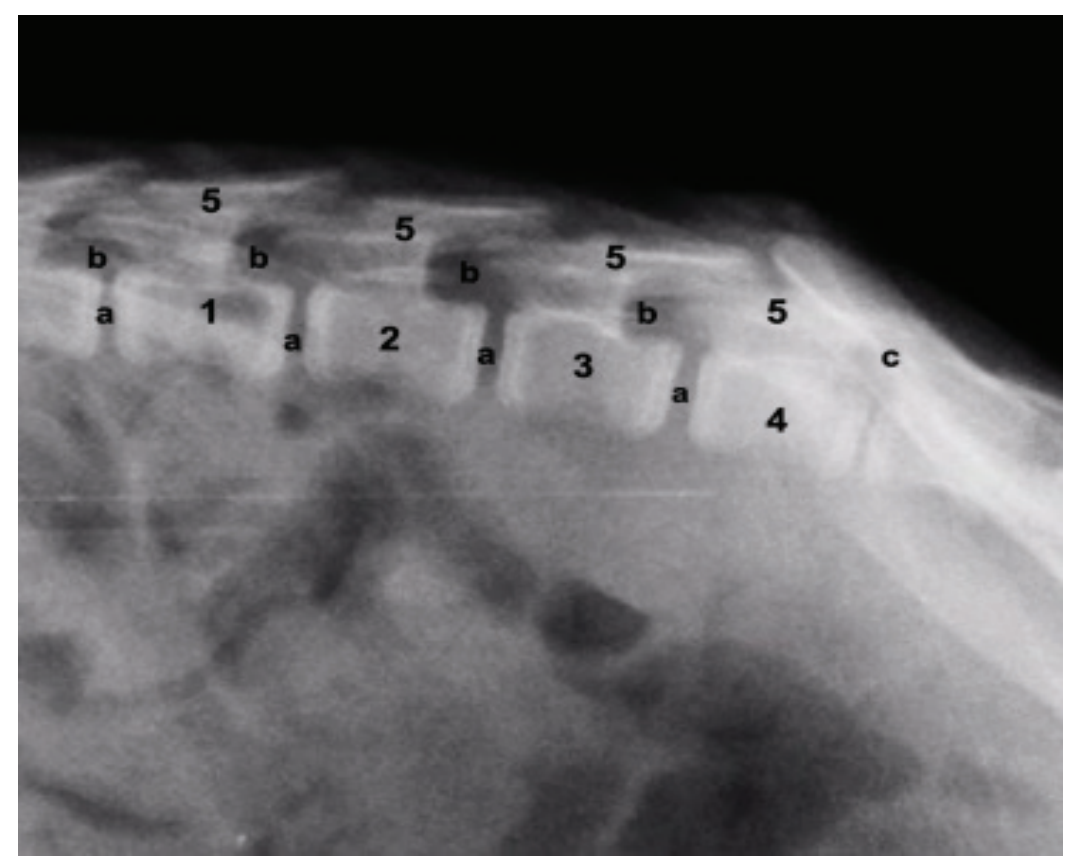

Figure 10. Right laterolateral $\mathrm{X}$-rays showing the lumbar vertebrae of the $C$. boffmanni. (1) Vertebral body of L1, (2) vertebral body of L2, (3) vertebral body of L3, (4) vertebral body of L4,(5) spinous process, (a) intervertebral space, (b) intervertebral foramen, (c) lumbosacral interarcuate space. Photograph by the authors.

\section{Sacral Vertebrae}

In mammals the sacral vertebrae fuse together into a single structure called sacrum. Xenarthrans generally have their sacrum fused to their coxal bones forming a synsacrum. One of the four specimens studied had fractures in all of its coxal bones: pelvis, ilium, and ischium. Although fragments of the bones mentioned above were still fused to the sacrum. The clinical history of this specimen stated it had sustained injuries by a car. The only female was juvenile, meaning that its coxal bones and sacrum were not ossified together. Despite that, each bone was treated with hydrogen peroxide. The sacrum, ilium, ischium, and pubis were separated into different pieces after the cartilage de-attached itself. Osteology revealed that, in the adult samples, the ilium wing was fused with the transverse wing of the sacrum (S1-S4 vertebrae). The small prickly process of each sacral vertebra forms the medial sacral crest, assuming the form of a dorsal crest to the sacral vertebrae. The ischial tuberosity fuses with the last sacral vertebrae. Another feature is the presence of seven pairs of dorsal and ventral sacral holes. The promontory protrudes cranially and ventrally parallel to the cranial articular processes of the sacrum. The sacrum is hourglass-shaped, flat on both the ventral and dorsal sides. 


\section{Ciencias}

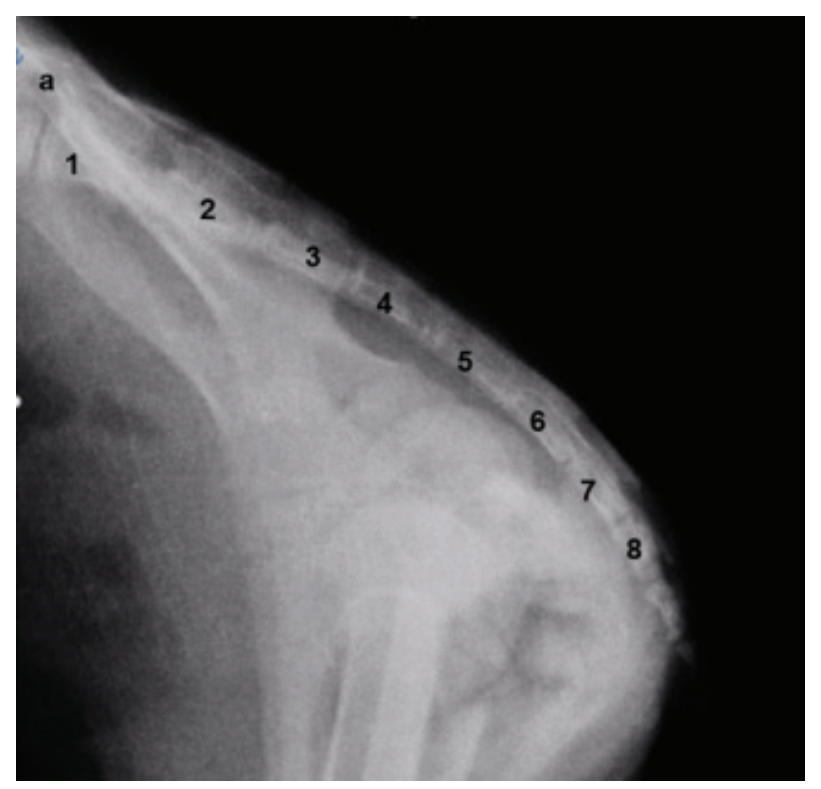

Figure 11. Right laterolateral X-ray showing the synsacrum of a C. hoffmanni. (1) $1^{\text {st }}$ sacral vertebra, (2) $2^{\text {nd }}$ sacral vertebra, (3) $3^{\text {rd }}$ sacral vertebra, (4) $4^{\text {th }}$ sacral vertebra, (5) $5^{\text {th }}$ sacral vertebra, (6) $6^{\text {th }}$ sacral vertebra, (7) $7^{\text {th }}$ sacral vertebra, (8) $8^{\text {th }}$ sacral vertebra, (a) lumbosacral interarcuate space. Photograph by the authors.

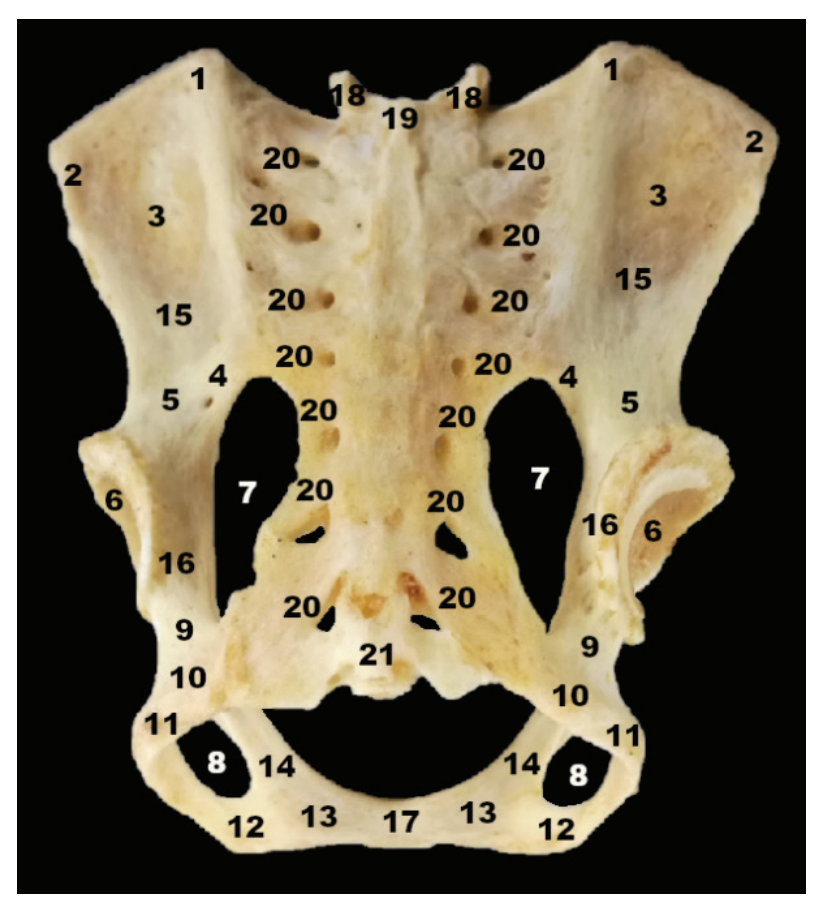

Figure 12. Dorsal photograph showing the intact synsacrum of a C. hoffmanni. (1) Iliac crest, (2) coxal tuberosity, (3), iliac surface (4), greater ischiatic notch (5) body of ilium, (6) acetabulum, (7) sacro-ischiatic foramen, (8) obturator foramen, (9) body of ischium, (10) ischial tuberosity, (11) branch of ischium, (12) cranial branch of pubis, (13) body of pubis, (14) caudal branch of pubis, (15) ilium, (16) ischium, (17) pubis, (18) cranial articular process, (19) median sacral crest, (20) dorsal sacral foramina, (21) caudal articular process. Photograph by the authors. 


\section{Caudal Vertebrae}

This species does not have anatomical differentiation in their caudal vertebrae; however, the transverse processes remain evident. These vertebrae come together to form a remarkably small tail in this species (Fig. 13). It was affirmed that the C. hoffmanni does not have a tail; however, upon closer inspection of the shaved animals a small stump was found attached caudally to the sacrum.

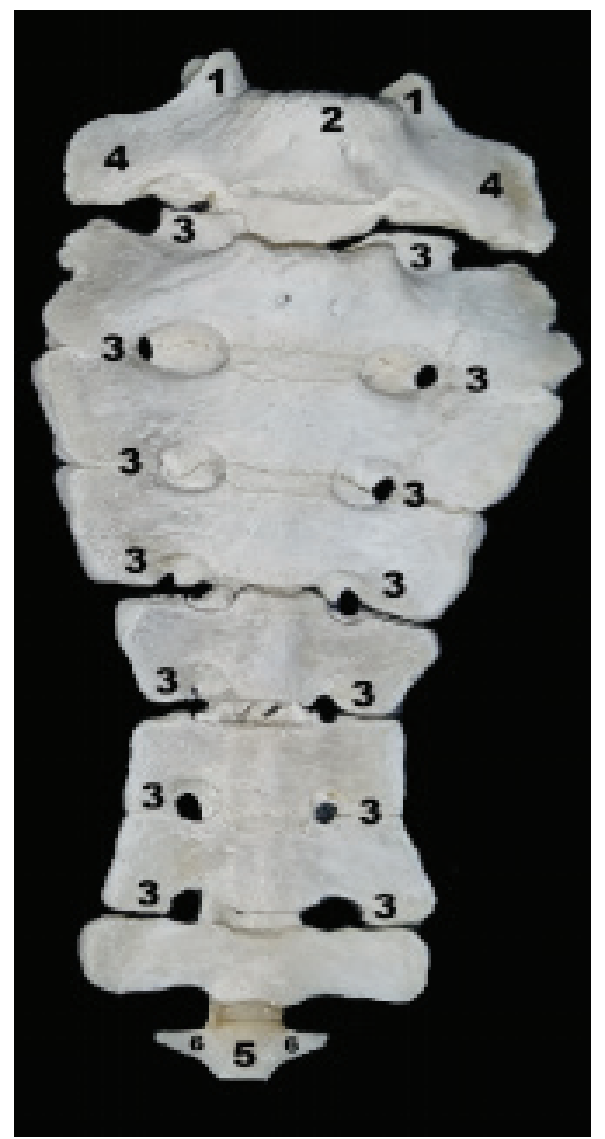

Figure 13. Ventral view of the juvenile sacrum. (1) Cranial articular process, (2) promontory, (3) ventral sacral foramina, (4) sacrum wing, (5) $1^{\text {st }}$ caudal vertebra, (6) transverse processes of the first caudal vertebra. Photograph by the authors.

\section{Discussion}

The C. hoffmanni, alongside its other Pilosa family members, and manatees are the only mammals that deviate from the usual "rule of seven" in the neck. Sloths will display either reduced or increased cervical counts. (Adam, 1999; Böhmer et al., 2018; Delsuc et al., 2002; Hautier et al., 2010; Montilla et al., 2016). The total number of cervical vertebrae observed in all studied specimens was six. 
The Choloepus didactylus is the closest living relative to C. boffmanni (Adam, 1999). The number of cervical vertebrae in $C$. didactylus is usually seven, but it can range from six to eight. This makes the $C$. didactylus likely to have more cervical vertebrae than the $C$. hoffmanni, approximating them to the common mammal cervical pattern. The Bradypus trydacylus and Bradypus variegatus have a total cervical count that can vary from eight to ten, but the most frequent number is nine (Bucholtz \& Stepien, 2009). Most other members of the Xenarthra order have the seven cervical vertebrae pattern; examples of this are the nine-banded armadillo (Dasypus novemcinctus) (Alves et al., 2017), and the giant anteater (Myrmecophaga tridactyla) (Borges et al., 2017).

C. hoffmani shares the abnormal cervical count with the Sirenia species like the manatees, which tend to have six cervical vertebrae (Buchholtz et al., 2007). The Orycteropus afer, commonly known as the aardvark, possesses overlapping transverse processes like the C. hoffmanni does in its cervical vertebrae (Owen, 2011). Focusing on the atlas specifically, $C$. hofmanni presents a complete alar foramen and a transverse foramen that are similar in domestic mammals, with the exception of Canis lupus familiaris, where the alar foramen is replaced with a notch (Lopez et al., 2008) and, in the case of Bos primigenius taurus, where the transverse foramen is absent (Konig \& Liebich, 2020). Furthermore, one important characteristic found in the cervical vertebrae is the different shape located in the sixth cervical vertebra of the juvenile female which fits the description of a transition vertebra. A vertebra that cannot be placed in the five classical vertebra types, either due to extra or lacking features, is defined as a transition vertebra (Varela-Lasheras et al., 2011). The C6 of the juvenile female had a distinct transverse process which could make that bone a transition vertebra. No other differences were found in the cervical area.

The atlas and the axis are both atypical vertebrae; their special characteristics allow them to carry out unique functions like supporting the head and performing flexion, extension, and lateralization. This is of special relevance in the case of $C$. hoffmani, which usually has a relatively short and robust neck and keeps its head upside-down during suspensory postures (Böhmer et al., 2018).

In function of clinical relevance, the atlantooccipital, atlantoaxial and lumbosacral interarcuate spaces were identified in radiographic images that are important as a local for the application of anesthetics and contrast media for anesthetic blockages and myelography, respectively (Shores \& Brisson 2017; Iseri et al., 2003).

Compared to most domestic mammals, the thoracic vertebrae do not have any major morphological differences (Konig \& Libich, 2020; Owen, 2011). It has been theorized that thoracic vertebrae can also be xenarthrous, having extra joints (Gaudin \& Biewener, 1992), but no evidence of this was found in the four specimens studied.

The most important particularity is the presence of twenty or more thoracic vertebrae that are connected with a pair of ribs each. In animals like horses or dogs, organs like the liver or kidneys are not completely protected by the ribcage (Konig \& Liebich, 2020). In sloths the ribcage is ample and encompasses the great majority of the animal's length. In Addition to the liver and the kidneys, this bone structure also encases the intestines. (Fig. 6). The high number of thoracic vertebrae and ribs can be explained as an adaptation for $C$. boffmanni's suspensory activity on the trees (Cliffe et al., 2014).

The withers in animals are an important reference point for taking height measurements in a lot of species. It can be pinpointed by the tallest spinous process in any thoracic vertebra that is located between the scapulae (Tamioso et al., 2012). The X-ray images taken (Fig. 6) demonstrated that the withers can be found at the 
second thoracic vertebra. The anticlinal vertebra is also of interest since it can be used as a reference point when working with imaging studies as a diagnosis tool. Multiple definitions and criteria exist for identifying the anticlinal vertebra; characteristics like the perpendicularity, verticality, and joint orientation of the spinous processes are all used to locate this vertebra (Baines et al., 2009). Despite taking the previous factors into account, upon closer inspection of the X-ray images obtained (Fig. 6) and through dissection it was not possible to identify any major changes in the configuration of the spinous process in any thoracic vertebra. This implies a lack of a well-defined anticlinal vertebra.

The definition of xenarthrous vertebrae established by Gaudin \& Biewener in 1992 accurately depicts how the mammillary and transverse processes in the C. hoffmanni come together to form an extra joint. Gaudin \& Biewener (1992) believed that xenarthrous joints existed in order to provide additional structural support to armadillos' spine when they require great force to curl to defend themselves. Sloths do not exhibit that exact behavior, however their distinct lifestyle may still require extra strength in the lumbar area. Several studies that have been published over the years have allowed great insight into the locomotion of the sloth (Nyakatura \& Fischer, 2010; Mendel, 1981). These animals use their thoracic limbs to pull all their weight while their pelvic limbs function as anchorage.

If the animal loses its grip with its thoracic limbs, it will have to rely on its pelvic limbs, which may place extra mechanical strain on the lumbar area. This could serve as an explanation for the persistence of xenarthrous vertebrae in the sloths (Bargo \& Nyakatura, 2018; Soibelzon et al., 2010). As reported by other authors, we also found a constant count of eight sacral vertebrae in all specimens studied after being verified by radiographic and osteological analysis (Galliari \& Carlini, 2018; Hayssen, 2011). The fusion of the sacrum with the coxal bones (Fig. 12), forming together a synsacrum, is a very well-understood characteristic of the xenarthrans (Galliari \& Carlini, 2018). However, because one female was juvenile the ossification process in her synsacrum was incomplete (Fig. 11); this meant that, upon dissection, her synsacrum separated into a sacrum, ischium, pubis, and ilium. It was concluded that this happened due to the age of the animal and not because of pathology.

\section{Conclusion}

The current gross morphological and radiographic study showed that some bones and foramina of the vertebral column of the two-toed sloth were quite similar to those of other xenarthrans and even other domestic mammals. Understanding characteristics, like high vertebral variability, ribcage structure and lumbar xenarthrosis, is important to make sure diagnoses and treatments are correctly delivered when working with the $C$. hoffmanni. The data gathered through this investigation is of relevance for academic, taxonomy, wildlife and forensic purposes. Moreover, it may help zoo veterinarians with clinical-surgical procedures.

\section{Conflicts of Interest}

The authors declare that they have no conflicts of interest. 


\section{Acknowledgments}

The authors acknowledge Dr. Laura Chaverri-Esquivel for her great collaboration in the academic training process. We also acknowledge Mr. Heiner Serrano-Alfaro for his significant technical assistance during the bones preparation and the radiographic imaging.

\section{References}

Adam, P.J. (1999). Choloepus didactylus. Mammalian Species. 621: 1-8. doi:10.2307/3504332

Miller, R. E., \& Fowler, M. E. (2014). Fowler's Zoo and Wild Animal Medicine, Volume 8 (8. ${ }^{a}$ ed.). Saunders. https://doi.org/10.1016/C2012-0-01362-2

Alves, L. S., Midon, M., Filadelpho, A. L., \& Vulcano, L. C. (2016). Gross Osteology, Radiographic and Computed Tomographic Morphology of the Axial Skeleton of the Nine-Banded Armadillo (Dasypus novemcinctus). Anatomia, Histologia, Embryologia, 46(2), 162-177.https://doi.org/10.1111/ahe.12247

Baines, E. A., Grandage, J., Herrtage, M. E., \& Baines, S. J. (2009). Radiographic definition of the anticlinal vertebra in the dog. Veterinary Radiology $\sigma^{\circ}$ Ultrasound, 50(1), 69-73. doi:10.1111/j.1740$\underline{8261.2008 .01492 . x}$

Susana Bargo, M., \& Nyakatura, J. A. (2017). Morphology and Evolution of the Xenarthra: an Introduction. Journal of Mammalian Evolution, 25(4), 445-447. https://doi.org/10.1007/s10914-017-9419-4

Böhmer, C., Amson, E., Arnold, P., van Heteren, A. H., Nyakatura, J.A. (2018). Homeotic transformations reflect departure from the mammalian 'rule of seven' cervical vertebrae in sloths: inferences on the Hox code and morphological modularity of the mammalian neck. BMC Evolutionary Biology, 18(84), 1-11. doi:10.1186/s12862-018-1202-5

Borges, N. C., Nardotto, J. R., Oliveira, R. S., Rüncos, L. H., Ribeiro, R. G., \& Bogoevich, A. M. (2017). Anatomy description of cervical region and hyoid apparatus in living giant anteaters Myrmecophaga tridactyla Linnaeus, 1758. Pesquisa Veterinária Brasileira, 37(11), 1345-1351. https://doi.org/10.1590/ $\underline{\text { s0100-736x2017001100025 }}$

Buchholtz, E. A., Booth, A. C., \& Webbink,K.E.(2007). Vertebralanatomy in the Florida manatee,Trichechus manatus latirostris: A developmental and evolutionary analysis. The Anatomical Record: Advances in Integrative Anatomy and Evolutionary Biology, 290(6), 624-637. https://doi.org/10.1002/ar.20534

Buchholtz, E.A. \& Stepien, C.C. (2009). Anatomical transformation in mammals: developmental origin of aberrant cervical anatomy in tree sloths. Evolution Eo Development, 11(1), 69-79. doi:10.1111/j.1525$\underline{142 X .2008 .00303 . X}$

Cliffe, R. N., Avey-Arroyo, J. A., Arroyo, F. J., Holton, M. D., \& Wilson, R. P. (2014). Mitigating the squash effect: sloths breathe easily upside down. Biology Letters, 10(4), 20140172. https://doi.org/10.1098/ rsbl.2014.0172

Delsuc, F., Scally, M., Madsen, O., Stanhope, M.J., De Jong W.W., Catzeflis F.M., Springer M.S. \& Douzery E.J.P. (2002). Molecular phylogeny of living Xenarthrans and the impact of character and 
taxon sampling on the placental tree rooting. Molecular Biology and Evolution, 19(10), 1656-1671. doi:10.1093/oxfordjournals.molbev.a003989

Galliari, F. C., \& Carlini, A. A. (2018). Xenarthran Synsacrum Morphology and Evolution. Journal of Mammalian Evolution, 26(4), 493-504. https://doi.org/10.1007/s10914-018-9442-0

Gardner, AL. 2016. Xenarthrans. Encyclopedia Britannica.https://www.britannica.com/animal/xenarthran

Gaudin, J., Biewener, A. (1992). The functional morphology of xenarthrous vertebrae in the armadillo Dasypus novemcinctus (Mammalia, Xenarthra). Journal of Morphology, 214 (1), 63-81. doi:10.1002/ jmor.1052140105

Gilmore, D.P., Da Costa, C.P. \& Duarte, D.P. (2001). Sloth biology: an update on their physiological ecology, behavior, and role as vectors of arthropods and arboviruses. Brazilian Journal of Medical and Biological Research 34(1), 9-25. doi:10.1590/s0100879x2001000100002

Hautier, L., Weisbecker, V., Sanchez-Villagra, M.R., GoswamiI, A. \& Asher, RJ. (2010). Skeletal development in sloths and the evolution of mammalian vertebral patterning. Proceedings of the National Academy of Sciences of the United States of America, 107(44), 18903-18908. doi:10.1073/pnas.1010335107

Hayssen, V. (2011). Choloepus hoffmanni (Pilosa: Megalonychidae). Mammalian Species, 43, 37-55. https:// doi.org/10.1644/873.1

Iseri, T., Yamada, K., \& Ueno, H. (2004). Lumbosacral Myelography in Dogs-A Safer Technique. Journal of Veterinary Medical Science, 66(1), 71-72. https://doi.org/10.1292/jvms.66.71

König, H.E. \& Liebich, H.G. (2020). Veterinary Anatomy of Domestic Mammals: Textbook and Colour Atlas. (7 ed.) Thieme.

Mendel, F. C. (1981). The hand of two-toed sloths (Choloepus hoffmanni): Its anatomy and potential uses relative to size of support. Journal of morphology, 169(1), 1-19. doi: 10.1002/jmor.1051690102.

Montilla-Rodriguez, M. A, Blanco-Rodríguez J. C, Nastar-Ceballos, R. N and Muñoz-Martínez, L. J. (2016). Anatomical Description of Bradypus variegatus in the Colombian Amazonia. Revista de la Facultad de Ciencias Veterinarias, Universidad Central de Venezuela, 57(1), 3-14. Disponible en: http:// ve.scielo.org/scielo.php?script=sci_arttext\&pid=S0258-65762016000100001

Nyakatura, J.A. \& Fischer, M.S. (2010). Functional morphology and three dimensional kinematics of the thoraco-lumbar region of the spine of the two toed sloth. Journal of Experimental Biology, 213, 42784290. doi:10.1242/jeb.047647

Nyakatura, J.A., Petrovitch \& A, Fischer, M.S. (2010). Limb kinematics during locomotion in the two-toed sloth (Choloepus didactylus, Xenarthra) and its implications for the evolution of the sloth locomotor apparatus. Zoology, 113(4), 221-234. doi:10.1016/j.zool.2009.11.003

Owen, R. (2011). On the Anatomy of Vertebrates, Volume: birds and mammals. Cambridge Library Collection - Zoology: Cambridge University Press. https://doi.org/10.1017/CBO9781139104111

Shores, A., \& Brisson, B.A.(Eds) (2017). Current techniques in canine and feline neurosurgery (1st ed.) John Wiley and Sons. 
Soibelzon, E., Miño-Boilini, A. R., Zurita, A. E., Krmpotic, C. M. (2010). The Xenarthra (Mammalia) from the Ensenadean (lower to middle Pleistocene) of the Pampean region (Argentina). Revista mexicana de ciencias geológicas, 27(3). http://www.scielo.org.mx/scielo.php?script=sci_arttext\&pid $=$ S1026-87742010000300004

Tamioso, P. R., Cosmo, T. R., Pimentel, C. M. M. M., Dias, L. T., Teixeira, R. A. (2012). Heritability estimates for body weight and height at withers in Brazilian army horses. Ciência Rural, 42(12), 22462251. doi: $10.1590 /$ S010384782012005000093

Torres-Trujillo, N. \& Mantilla-Meluk, H. (2016). Anotaciones sobre la distribución del perezoso de dos dedos Choloepus hoffmanni (Pilosa: Megalonychidae) para el departamento del Quindío, en las listas de mamíferos de Colombia. Investigación, Biodiversidad y Desarrollo 35(1), 20-30.

Varela-Lasheras, I., Bakker, A. J., van der Mije, S., Metz, J. A. J., Alphen, J., \& Galis, F. (2011). Breaking evolutionary and pleiotropic constraints in mammals: On sloths, manatees and homeotic mutations. EvoDevo, 2(12). doi:10.1186/2041-9139-2-11 